\title{
Examining of the Predictors of Pre-service Teachers' Perceptions of the Quality of the Science Fair Projects in Turkey
}

\author{
Hasan Said TORTOP* \\ Bulent Ecevit University, Zonguldak, TURKEY
}

Received: 08.10 .2013

Accepted: 26.02 .2014

\begin{abstract}
This study aimed at examining the predictors of quality of science fair (SF) projects in the light of pre-service teachers' evaluation of SF rubric' domains. These projects were selected by judges in A city for the A Regional Exhibition of Science and Mathematics Project Study for Primary School Students: The SF projects were evaluated by thirty junior pre-service teachers who took the Projects Based Learning Applications course at A University A Faculty of Education in the Fall Term of the academic year of 2011-2012. The results of study revealed that the lowest mean scores of the domain of SF rubric was the method domain $(\bar{X}=1.35)$, and the highest mean scores of the domain of SF rubric was the utility domain $(\bar{X}=1.64)$ according to the results of the descriptive statistics. Surprisingly, the methods domain was one of the weakest predictors of overall scores of the SF rubric. It is important that project competitions and project based learning applications should do to help students to gain the scientific research skills. The necessary steps should be taken to help teachers and preservice teachers to look at the science fair and preparing SF projects from this perspective.
\end{abstract}

Key Words: science fair, judgment, scientific research projects, regression analysis

DOI No: 10.12973/nefmed.2014.8.1.a2

\section{Introduction}

The 1960s was a period when science education gained importance and when the policies of training scientists were on the agenda. It is seen that science programs changed in many developed and developing countries (McGee, 1996; Breederman, 1983; Kelly \& Staver; 2005; DeBoer, 1991). In that period, Turkey was also among those countries that were influenced by this change (Demirbas \& Yagbasan, 2005). In addition, it was seen in that

\footnotetext{
* Corresponding author: Hasan Said TORTOP, Assist.Prof. Department of Science Education, Eregli Faculty of Education, Bulent Ecevit University, Zonguldak, TURKEY.

E-mail: hasansaid@yahoo.com
}

Note: This study was partially presented as a procedings at 9th International Conference on Hands-on Science 
period that students learnt to behave like scientists and that project competition (science fairs) which allowed students to act like a scientist were commonly used. In Turkey, such attempts were made at the high school level with the help of The Scientific and Technological Research Council of Turkey (STRCT) in 1968 [STRCT, 2012)]. Today, it is seen that a number of countries have revised their science programs to train individuals equipped with the $21^{\text {st }}$ century skills (such as collaboration, critical thinking, communication, creativity and innovation, self-direction) (Ravitz, Hixson, English \& Mergendoller, 2011). Turkey changed the primary school curriculum of the science and technology course to make it aligned with the constructivist approach in 2005. The purpose of the new science curriculum was to train individuals who can research, interrogate, examine, associate science subjects with daily life and use scientific methods to solve the problems in every field of life and know how to view the world from the perspective of a scientist (Board of Education, 2005). In Turkey, the Secondary School Students' Project Competitions have been organized by STRCT and MNE (Ministry of National Education) for a long time. In addition, a similar competition named Science and Mathematics Project Work for Primary School Students has also been taken place at the elementary school level with the cooperation of STRCT and MNE since the academic year of 2005-2006 (STRCT, 2012; RDED, 2012). Science fairs, which have become a tradition in developed countries, are exhibitions open to the public in which students present their works (independent scientific research). In general, in these science fairs, juries make evaluations, and students are awarded based on their projects (Bunderson \& Anderson, 2006; Abernathy \& Vineyard, 2001). A science fair regarded as a celebration by Abernathy and Vineyard (2001) is defined as a place in which students share their studies with their friends, teachers, parents, scientists and other people in the society and make interpretations regarding their experiences. The primary purpose of science fairs is to help students to understand and use scientific methods while designing and conducting experiments so that they can achieve their school program. Besides such benefits of science fairs as teaching students new things, spending enjoyable time, developing their research skills and helping them to think critically and develop positive attitudes towards science, these science fairs also cause students to feel worried and stressed at the end of the competition and increase their anxiety level (Grote,1995; Bunderson \& Anderson, 1996; Abernathy \& Vineyard, 2001; Czerniak, 1996; Balas, 1998; Bellipanni \& Lilly, 1999; Wang \& Yang, 2003; Gomez, 2007; Kankelborg, 2005; Yayla, \& Uzun, 2008; Fisanick, 2010).

In the competition of 'This is My Work' and in the other similar project competitions, the purpose is to have young brains think and make observations, to encourage them to 
wonder and research and to help them to reveal their potentials. In addition, it is an important result that the idea behind the project belongs totally to the student(s) (STRCT, 2012; RDED, 2012). The criteria for the evaluation of the works in these competitions are stated in competition guides. Although there seems to be much diversity in the evaluation of the works in provincial, regional and final exhibitions, it is generally stated by juries that the following criteria should be taken into consideration during evaluation: STRCT Evaluation Criteria 2009-2010 Project Guide, originality and creativity, used scientific method, consistency and contribution, utility (economic, social academic, ...), applicability or usefulness, literature review, conclusion and clarity, assimilation and mastery and obeying the safety warnings. There are a number of studies which emphasize the importance of the jury's evaluation in project competitions and which point out that the projects developed should be belong to the students. These are quite important for the quality of the competitions and for students' development (Grobman, 1993; Shore, Delcourt, Syre \& Shapiro, 2007; Czerniak \& Lumpe, 1996). In this respect, the evaluation of projects is fairly important. Such questions as "according to which dimension of the evaluation criteria are some projects developed by students considered to be better than those developed by other students?" or "to which aspects of the projects do the juries evaluating them to give more importance in the evaluation process?" occupy the minds of students participating in project competitions as well as of their supervisors (Potter, 2009). Potter (2009) examines the quality of the science fair rubrics, and she argues that science fair rubrics are not only a summative rubric, but also they are formative rubrics. Besides, she examined the extent to which patterns in student performance, as measured by the Potter Rubrics, predict the judges' perception of the quality of the Project.

This study examined to what extent the criteria in the evaluation scale determined by STRCT and Potter Rubrics (2009) in the Science and Mathematics Project Work for Elementary School Students also known as 'This is My Work' started in elementary school level in Turkey in the academic year of 2005-2006 predict the total score in the evaluation. For this purpose, the following research questions were directed:

What is the order of importance of the criteria in the evaluation scale (STRCT Rubric) in the project competition of 'This is My Work' according to the pre-service teachers?

$>$ To what extent does the criterion in the evaluation scale (STRCT Rubric) in the project competition of 'This is My Work' predict the total score given in the evaluation process by the pre-service teachers? 
$>$ To what extent does the criteria in the evaluation scale (Potter' Rubric, 2009) in the project competition of 'This is My Work' predict the total score given in the evaluation process by the pre-service teachers?

$>$ Are there any relations between STRCT project evaluation rubric scores and Potter's (2009) science fair project evaluation scores?

\section{Methods}

This study used a correlation research design (Buyukozturk, Cakmak, Akgun, Karadeniz \& Demirel, 2011). Relation of pre-service teachers' perception of quality (high, medium, low) between primary school students' scores of projects according to STRCT Rubrics and Potter Rubrics were examined. The dependent variable was the perception of quality (high, medium, low), and the independent variable was the score each pre-service teachers gave for each project in each domain (Potter, 2009).

\section{Procedure}

In this study, thirty projects were determined for evaluation by pre-service teachers. These projects were selected by judges in A city for the A Regional Science Fair Exhibition of "Science and Mathematics Project Study for Primary School Students: This is My Work" Science Fair (web address: http://tegm.meb.gov.tr/bubenimeserim/) in the academic year of 2009-2010. The researcher was also a mentor for this science fair. Tortop (2013b) examined all aspects of this science fair by looking at the views of administrators, teachers and students. The quality of the projects was also examined by experts in the field of science education. In this study, the same thirty projects (Tortop, 2013b) were selected and examined in terms of the quality of projects by pre-service teachers.

\section{Participants}

In this study, while selecting of participants who will evaluate projects, some certain criteria are taken into account. The first criteria is that pre-service teachers should be at a certain level at which they gain educational acquisitions. In this respect pre-service teachers should be at the third class level (junior) at least. The second criteria is that pre-service teachers should be trained in Project based learning model and science fair. So, as participants, thirty pre-service teachers who took the Projects Based Learning Applications course at A University in the Faculty of Education in the Fall Term of the academic year of 2011-2012 in Turkey, were determined. The pre-service teachers assessed the projects according to the criteria of the project guide and Potter Rubrics ("This is My Work" Science Fair Project Guide, 2009; Potter, 2009). 
The pre-service teachers assigned such scores to the dimensions determined in the evaluation scale as "1" inefficient, "2" efficient and "3" very efficient (Potter, 2009; Tortop, 2013b).

Data Analysis

Descriptive analysis was used for assessment of science fair project quality scores according to sub-dimension (such as originality, using the scientific method) of STRCT Rubrics and Potter Rubrics at SPSS program. Mean scores and standard deviation were calculated for every sub-dimension of STRCT Rubrics and Potter Rubrics.

Besides, in order to determine the predictors of the sub-dimension of STRCT Rubric and Potter Rubric scores related to STRCT Rubric and Potter Rubric total quality scores Multiple Linear Regression (Stepwise) and Pearson Product Moment Correlation were used in the SPSS program (Buyukozturk et al., 2010).

\section{Results}

In the conducted study, 30 projects that were admitted to the regional exhibition were evaluated by 30 pre-service teachers. In this evaluation, the criteria determined by STRCT were taken into consideration (This is My Work Project Guide, 2009). Among these criteria, "taking safety measures" and "giving reference" were not included in the analyses as all of the 30 projects had common deficiencies in these dimensions.

\section{Results of First Research Question}

As a result of the evaluation of 30 projects that pre-service teachers conducted using the STRCT rubric, subscale average scores are shown in Table 2. For assessment of a science fair Project according to STRCT Rubric lowest score is " 1 ", and highest score is " 3 " for each sub-dimension. And total quality scores for a science fair Project low score is "7", and the high score is " 21 ".

Table 1 Descriptive Statistics of Rubric

\begin{tabular}{lcc}
\hline & Mean & Std. Deviation \\
\hline Total Score & 13,2333 & 2,9431 \\
\hline Orginality and Creativity Domain & 1,6089 &, 6331 \\
\hline Used Scientific Method Domain & 1,3533 &, 4965 \\
\hline Consistency Domain & 1,4589 &, 5183 \\
\hline Utility for Economical and Social Domain & 1,6489 &, 5976 \\
\hline Applicability and Usefulness Domain & 1,4844 &, 5668 \\
\hline Conclusion and Clarity Domain & 1,4656 &, 5459 \\
\hline Assimilation and Comprehension Domain & 1,4567 &, 5453 \\
\hline
\end{tabular}

Necatibey Eğitim Fakültesi Elektronik Fen ve Matematik Eğitimi Dergisi 
As it can be seen in Table 1, the average of the highest quality score of the science fair projects is in the dimension of usability and originality. The average score of the lowest quality is seen in the dimension of the scientific method. This situation can be interpreted as; teachers, consulting projects, give little attention to this dimension and the jury groups that choose region exhibition, give very little importance to quality in this dimension.

\section{Results of Second Research Question}

The results of the regression analysis regarding the prediction of the total scores (according to STRCT Rubric) in the project evaluation are presented in the Table 2. In addition, further analyses were conducted by the stepwise method as one of the regression analysis methods.

Table 2 Multiple Linear Regression (Stepwise) Predicting Overall Quality (according to STRCT Rubric) with Domains

\begin{tabular}{ccc}
\hline Unstandardi & Standardized & Correlatio \\
zed & Coefficients & ns \\
Coefficients & &
\end{tabular}

\begin{tabular}{|c|c|c|c|c|c|c|c|}
\hline Model g & B & Std. Error & $\beta$ & $\mathrm{t}$ & sig & $\begin{array}{c}\text { Zero Order } \\
\mathrm{r}\end{array}$ & Partial r \\
\hline Constant & 1,204 & ,116 & & 10,420 & ,000 & & \\
\hline Consistency & 1,103 & ,060 & ,194 & 18,440 & ,000 & ,573 & ,576 \\
\hline Assimilation & 1,421 & ,055 & 263 & 25,997 & ,000 & ,502 & ,529 \\
\hline Applicability & 1,190 & ,054 & 229 & 21,894 & ,000 & ,644 & 476 \\
\hline Clearness & 1,227 & ,046 & ,263 & 26,477 & ,000 &, 576 &, 528 \\
\hline Originality & 1,021 & ,046 & ,220 & 22,036 & ,000 & ,614 & ,549 \\
\hline Methods & 1,108 & ,057 & ,187 & 19,433 & ,000 & ,642 & ,597 \\
\hline Utility & ,988 & ,051 & ,201 & 19,408 & ,000 & ,641 & ,604 \\
\hline \multicolumn{8}{|c|}{$\mathrm{R}=, 964 \mathrm{R}^{2}=0.93$} \\
\hline \multicolumn{8}{|c|}{$\mathrm{F}_{(7-892)}=1454,178 \mathrm{p}=, 000$} \\
\hline
\end{tabular}

When the paired and partial correlations between the predictive variables and the dependent variable (total score) were examined, it was seen that the highest relationship occurred between the Total Score and the Dimension of Consistency ( $\mathrm{r}=.644)$; however, when the other variables were examined, the correlation between the two variables was found to be 
$\mathrm{r}=.525$. The variables that had a high level of relationship with the total score were Consistency ( $\mathrm{r}=.644)$, Assimilation ( $\mathrm{r}=.641)$, Applicability ( $\mathrm{r}=.614)$, Conclusion (.607), Utility ( $\mathrm{r}=.576)$, Originality $(\mathrm{r}=.573)$ and Method (.502), respectively. The Project Evaluation Form, with its all sub-dimensions, revealed a high level of significant relationship $(r=.96$, $\left.\mathrm{R}^{2}=093 \mathrm{p}<.001\right)$. All the dimensions explained approximately $93 \%$ of the total variance in the total evaluation score. According to the standardized regression coefficient $(\beta)$, the relative order of importance of the total evaluation score of the predictive variables was as follows: Assimilation (.263), Clearness (.263), Applicability (.229), Originality (.220), Utility (.201), Consistency (.194) and Method (.187). When the results of the t-test regarding the significance of the regression coefficients were examined, all the dimensions were found to be significant predictors. Below is the mathematical model for the regression equation regarding the prediction of the total scores of the Project Evaluation Scale.

Project Evaluation Scale Score $=1.204+.263$ [Assimilation] +.263 [Clearness] + $.229[$ Applicability] $+.220[$ Originality] $+.201[$ Utility] $+.194[$ Consistency $]+.187[$ Method]

As can be seen here, the least predictive dimension in the evaluation of the projects is the "Method" dimension, and the most predictive dimensions were "Assimilation" and "Clearness".

\section{Results of Third Research Question}

The results of the regression analysis regarding the prediction of the total scores (according to Potter' (2009) Rubric) in the project evaluation are presented in the Table 3. In addition, further analyses were conducted by the stepwise method, one of regression analysis methods.

Table 3 Multiple Linear Regression (Stepwise) Predicting Overall Quality (according to Potter' (2009) Rubric) with Domains

\begin{tabular}{lccccccc}
\hline & B & Std Error & $\beta$ & $\mathrm{p}$ & $\mathrm{p}$ & \multicolumn{2}{c}{ Zero order Partial $\mathrm{r}$} \\
& & & & & & & $\mathrm{r}$ \\
\hline Constant & $4,820 \mathrm{E}-15$ & & & & & & \\
\hline Background & 1,000 &, 000 &, 371 & - & - &, 702 & 1,000 \\
\hline Methods & 1,000 &, 000 &, 352 & - & - &, 697 & 1,000 \\
\hline Data Collection & 1,000 &, 000 &, 336 & - & - &, 711 & 1,000 \\
\hline Analysis & 1,000 &, 000 &, 336 & - & - &, 759 & 1,000 \\
\hline $\mathrm{R}=1.000 \mathrm{R}^{2}=1.000$ & & & & & & & \\
\hline $\mathrm{F}_{(4-895)}=1981.64$ & $\mathrm{p}=, 000$ & & & & & & \\
\hline
\end{tabular}


The following model is seen when the sub-dimensions of the total score of rating scale that was used by Potter' Rubric (2009), is analyzed.

Project Evaluation Scale Scores $=$ Constant +.371 [Background Dimension $]+.352$ [Methods Dimension] .336 [Data Collection Dimension] + .336 [Analysis Dimension]

\section{Results of Fourth Research Question}

The results of the correlation analysis regarding the total scores of Potter' (2009) Rubric between STRCT Rubric in the project evaluation are presented in the Table 4. Pearson Product Moment Correlation was conducted with the statistic analysis methods.

Table 4 Correlation of STRCT Rubric Total Quality Scores between Potter' (2009) Rubric Total Quality Scores

\begin{tabular}{llc}
\hline & & Potter' Rubric \\
\hline STRCT Rubric & Pearson Correlation &, $717^{* *}$ \\
\hline Sig. (2-tailed) &, 000 \\
\hline $\mathrm{N}$ & 900 \\
\hline
\end{tabular}

** Correlation is significant at the 0.01 level (2-tailed).

As it can be seen in Table 4, there is a highly significant correlation between STRCT Rubric scores and Potter's Rubric scores $(r=.717, \mathrm{p}<.005)$.

\section{Discussion and Conclusion}

It is believed that science fairs can benefit students about scientific skills such as the scientific research (Grote, 1995; STRCT, 2013; Yayla \& Uzun; 2008; LaBanca, 2008; Fisanick, 2010), science interest or career path (Olsen, 1985; Yayla \& Uzun, 2008; Dionne et al., 2012), collaboration with peers (Yayla \& Uzun, 2008; Fisanick, 2010) and so they have become a common practice and tradition in many countries (Cook, 2003; LaBanca, 2008). However, there are still some problems about science fairs such as academic plagiarism (dishonesty) (Grobman, 1993; Syre \& Shapiro, 2007; Shore et al., 2007; Shore \& Delcourt, 1995, Syer \& Shore, 2001; Tortop, 2013a; Tortop, 2013b) and anxiety (Fisanick, 2010; Shore et al., 2007; Kosick, 2009; Czerniak \& Lumpe, 1996; Abernathy \& Vineyard, 2001). While the high school level science fairs at the high school level started in 1968 in Turkey, the secondary school level science fairs "This is My Work" began in 2005-2006. A comprehensive study of all aspects of "This is my Work" science fairs was done by Tortop 
(2013b). In the study, mostly teachers stated that "I do not want to participate as a mentor, in the competition if not necessary", this attitude of teachers affects the quality of the competition, of course. (Tortop, 2013b, 2013c).

One implication of teachers' negative attitudes about the science fair is that the jury evaluation cannot be relied on. Same findings that students and administrators concerned about the quality of jury evaluation (Tortop, 2013a, 2013b). There are also errors about the evaluation of the jury and academic plagiarism in literature (Grote, 1995a, Cook, 2003; Grobman, 1993; Syre \& Shapiro, 2007). Mistakes in jury that contradicts the aims of the competitions can lead the students and the teachers go in the wrong direction (Tortop, 2013a, Tortop, 2013b; Cook, 2003).

In this study, the pre-service teachers were asked to evaluate 30 projects selected in the regional science fair exhibition. The STRCT and Potter (2009) rating scales were used to measure the quality of the projects. The findings are quite remarkable. In the study, the lowest mean scores of the domain of science fair rubric were the Method domain $(\bar{X}=1.35)$, and the highest mean scores of the domain of the science fair rubric were the Utility domain $(\bar{X}=1.64)$ according to the results of the descriptive statistics.

In science fair guidelines, while students are expected to acquire scientific method skills and perceive themselves as a scientist, in the evaluation, the situation of having the lowest score in scientific method shows that students and teachers pay little attention to this dimension and the juries did not eliminate the participants who paid little attention to the scientific method dimension.

In addition, the model of regression formula was that; Overall Scores of Science Fair Rubric $=1.165$ (constant) +.251 (Assimilation and Comprehension Domain) + $.250($ Conclusion and Clarity Domain) +.225 (Originality and Creativity Domain) + .221 (Applicability and Usefulness Domain) +.205 (Utility for Economical and Social Domain) +.192 (Used Scientific Method Domain) +.184 (Consistency Domain). Surprisingly, the Methods domain was one of the lowest predictors of the overall scores of the science fair rubric.

These findings show that pre-service teachers hold such a perception; in determining the quality of a project in terms of scientific quality, the scientific method dimension that is used, is the least important dimension and assimilation and originality dimension of quality of the science projects, is more important. A similar situation can also be seen among students who look for the projects and among teachers who mentor the students in the district science fair 
exhibition. This situation can cause developing of a false perception about science by students who newly meet the science at secondary school level, therefore it is problematic for students' future science education (Czerniak, 1996; Cook, 2003; Blenis, 2000; Fisanick, 2010; Tortop, 2013a, Tortop; 2013b).

However, Potter (2009) found out that "the students' mean scores in the domains of Method and Analysis did predict the students' mean Quality scores". In this respect, the results obtained in the present study are parallel to those of the study carried out by Potter (2009). Potter (2009) reported that the dimensions of Method and Analysis were the best predictors for the project scale developed by the researcher. However, depending on this situation, the researcher stated that students and supervisor teachers in project competitions should not ignore the importance of the other dimensions of the scale. According to Potter (2009), juries evaluating the dimensions of Method and Analysis, which are the best predictors of the overall score, should focus on evaluating these dimensions due to their limited time. These findings obtained via the results of teacher candidates' evaluations of the projects are quite remarkable and thoughtful. Because, the "scientific method" that students used while preparing their projects least predicted the overall score. In fact, this indicates which features of projects that teacher candidates take into consideration while evaluating the projects. The new science program in Turkey (MNE; 2012) aims to help students acquire the ability to conduct scientific research. Science teachers should train students who know the scientific methods necessary to conduct scientific research (Grote, 1995; Cook, 2003; Abenarty and Vineyard, 2001; Tortop, 2013a, 2013b, 2013d). It is important that project competitions serve this purpose. The necessary precautions should be taken to help teacher candidates to view projects and project competitions from this perspective.

In the evaluation of pre-service teachers using Potter' (2009) Rubric, it is seen that "scientific method" isn't the highest predictor. Instead, surprisingly, "general information" dimension is the highest predictor. Pre-service teachers conducted a detailed examination, describing the project well and demonstrating that their projects had been of high quality. This situation is seen that Tortop (2013b) findings about teacher views of the science fairs in Turkey. A teacher's statement "Students cannot do this project, I do not understand how they are selected by juries" is quite significant.

Another finding is that there is a high correlation between STRCT rubric and Potter (2009) rubric. This is important in terms of the validity of the scales used in science fairs. However, what is important is that the jury should be trained about which sub-dimensions they should pay attention to (Grote, 1995, Tortop, 2013a, 2013b, Bellipani, 1994). However, 
according to the results of the study, "Scientific Method" sub-dimension of STRCT Rubric is high predictors of total quality scores, as well as high predictors of Potter Rubric total quality scores.

Science fair projects are tools that are used to measure students' performance assessment (Messick, 1995). It is needed to develop new assessment tools to assess students' science projects in terms of their performance. And "science educators only need to consider students' performance in Methods and Analysis when making decisions about student achievement" (Potter, 2009, pp.46) in the context of science fairs. Besides pre-service teachers should undergo training about what students should pay attention to scientific research projects within the project-based learning applications. In Turkey, Ministry of Education took a decision that science teachers can take additional courses for science fair mentorship. Although the certification is asked in all other additional courses (folk dance, table tennis, etc.), certificate is not required for the exercise in this area. Teachers should undergo training for doing a mentorship at the science fairs, they should take a certificate from STRCT or universities.

\section{References}

Abernathy, T.V., \& Vineyard, R.N. (2001). Academic competitions in science. Clearing House, 74(5), 269-277.

Balas, A.K. (1998). Science fairs in elementary school, ERIC clearinghouse for science mathematics and environmental education Columbus OH., 1-5, (ERIC document reproduction service No. ED 432444)

Blenis, D.S. (2000). The effects of mandatory, competitive science fairs on fifth grade students' attitudes toward science and interest in science. Reports-research (143), 26 pp. Retriewed from: http://www.eric.ed.gov/PDFS/ED443718.pdf

Bellipanni, L.J., \& Lilly, J.E. (1999). What have researchers been saying about science fairs? Science and Children, 99, 46-50.

Board of Education, (2005). Talim Terbiye Kurulu Başkanlığı. Retriewed from: http://ttkb.meb.gov.tr/

Breederman, T. (1983). Effects of activity- based elementary science on student outcomes: a quantitative synthesis. Review of Educatioanal Research, 53(4), 499-518.

Bunderson, E.D., \& Anderson, T. (1996). Preservice elementary teachers' attitudes toward their past experiences with science fairs. School Science \& Mathematics, 96(7), 371378. 
Czerniak, C.M. (1996). Predictors of success in a district science fair competition: An exploratory study. School Science \& Mathematics, 96(1), 21-28.

Buyukozturk, S., Cakmak, E.K., Akgun, O.E., Karadeniz, S., \& Demirel, F. (2011). Bilimsel araştırma yöntemleri [Scientific research methods], $8^{\text {th }}$ Edition, Ankara: PegemA Yayıncilik.

Cook, H.M. (2003). Elementary school teachers and successful science fair. The University of North Carolina.Unpublished Doctoral Thesis. Greensboro. Umi: 3093864

Czerniak, C.M. (1996). Predictors of success in a district science fair competition: An exploratory study. School Science \& Mathematics, 96(1), 21-28.

Czerniak, C.M., \& Lumpe A.T. (1996). Predictors of science fair participation using the theory of planned behavior. School science \& Mathematics, 97(7), 335-362

DeBoer, G., (1991). A history of ideas in science education. New York: Teachers College Press.

Demirbas, M., \& Yagbasan, R. (2005). Türkiye'de etkili fen öğretimi için ilköğretim kurumlarına yönelik olarak gerçekleştirilen program geliştirme çalışmalarının analizi ve karşılaş1lan problemlere yönelik çözüm önerileri. Gazi Üniversitesi Kırşehir Eğitim Fakültesi, 6(2), 53-67.

Dionne, L., Reis, G., Trudel, L., Guillet, G., Kleine, L., Hancianu, C. (2012). Students' sources of motivation for participating in science fairs: an exploratory study within the Canada-wide science fair 2008. International Journal of Science and Mathematics Education, 10(3), 669-693.

Fisanick, L. M. (2010). A descriptive study of the middle school science teacher behavior for required student participation in science fair competitions. Unpublished Doctoral Thesis. Pennsylvania University. Indiana. UMI Number: 3403187

Gomez, K. (2007). Negotiating discourses: sixth-grade students' use of multiple science discourses during a science fair presentation. Linguistics and Education, 18, 41-64.

Grobman, (1993). A fair proposition? The Science Teacher. 60(1), 40-41.

Grote, M. (1995a). Science teacher educators' opinions about science projects and science fairs. Journal of Science Teacher Education, 6(1), 48-52.

Grote, M. (1995b). Teacher opinions concerning science projects and science fairs. Ohio Journal of Science, 95(4), 274-277.

Kankelborg, A. (2005). Rural science fair competition: leveling the playing field. Unpublished Master thesis. Montana University, Montana. UMI: EP31005 
Kelly, M. P., \& Staver, J.R. (2005). A case study of one school system's adoptation and implementation of an elementary science program. Journal of Research in Science Teaching, 40(1), 25-52.

LaBanca, F. (2008). Impact of problem finding on the quality of authentic open inquiry science research projects. Unpublished Doctoral Thesis. Western Connecticut State University. UMI Number: 3411366.

Messick, S. (1995). Standards of validity and the validity standards in performance assessment. Educational Measurement: Issues and Practice, 14, 5-8.

McGee, S.M. (1996). Submitted to the graduate school in partial fulfillment of the requirements. Unpublished Doctoral Thesis. Northwestern University, Illinois, US.

Potter, M.C. (2009). Analyzing the technical quality of a rubric used to assess science fair projects. Unpublished Doctoral Thesis. University of Oregon. Oregon. UMI: 3377391

Ravitz, J., Hixson, N., English M., \& Mergendoller, J. (April, 2011). Using project based learnign to teach $21^{\text {st }}$ century skills: Findings from a statewide initiative. Paper presented at Annual Meetings of the American Educational Research. Vancouver, BC.

Research and Development of Education Department (RDED), Turkish Ministry of Education, (2012). Retriewed from: http://egitek.meb.gov.tr/earged/index.html

Shore, B.M., Delcourt, M.A.B., Syre, C.A., \& Shapiro, M. (2007). The phantom of the science fair. In B. M. Shore, M. W. Aulls, \& M. A. B. Delcourt (Eds.), Inquiry in education volume II: overcoming barriers to successful implementation. Mahwah, NJ: Erlbaum.

STRCT (2013). The Scientific and Technological Research Council of Turkey (STRCT). (TUBİTAK) Retriewed from: http://www.tubitak.gov.tr/ch

Syer, C.A., \& Shore, B.M. (2001). Science fairs: what are the sources of help for students and how prevalent is cheating?, School Science \& Mathematics, 101(4), 206-221.

This is My Work Science Fair Project Guide, (2009). Director of Basic Education. Retriewed from: http://tegm.meb.gov.tr/bubenimeserim/

Tortop, H.S. (2013a). Science teachers' views about the science fair at primary education level. Turkish Journal of Qualitative Inqury, 4(2), 56-64.

Tortop, H.S. (2013b). Bu benim eserim bilim şenliğinin yönetici, öğretmen ve öğrenci görüşleri ve fen projelerinin kalitesi odağından görünümü, [Overview of a national science fair in turkey from the focus on administrators', teachers', students' views and 
quality of science projects]. Adlyaman Üniversitesi Sosyal Bilimler Enstitüsü Dergisi, 6(11), 255-308.

Tortop, H.S. (2013c). Development of teacher attitude scale towards science fair. Educational Research and Reviews, 8(2), 58-62.

Tortop, H.S. (2013d). Development of teachers' self-efficacy beliefs scale through the science fair mentorship. Unpublished study.

Wang, X.H., \& Yang, B.Z. (2003). Why competition may discourage students from learning? A behavioral economic analysis. Education Economics, 11(2), 117-128.

Yayla, Z., \& Uzun, B. (September, 2008). Fen ve teknoloji eğitiminde proje çalışmaları ve bilim şenlikleri [Projects studies and science fair in science education]. XVII. Ulusal ĕgitim bilimleri kongresi. Sakarya, Turkey.

\title{
Türkiye'deki Öğretmen Adaylarının Bilim Şenliği Projelerinin Kalitesine İlişkin Algılarının Yordayıcılarının Incelenmesi Hasan Said TORTOP
} Bulent Ecevit Universitesi, Zonguldak, TURKEY Makale Gönderme Tarihi: 08.10.2013

Kabul Tarihi: 26.02.2014

\begin{abstract}
Özet - Bu çalışmanın amacı bilim şenliği (BŞ) değerlendirme ölçeği kullanılarak öğretmen adaylarının bir projenin kalitesine ilişkin yordayıcılarının incelenmesidir. Bunun için Türkiye'deki bir A ilinden A Bölge Sergisine (Illköğretim Öğrencileri Fen ve Matematik Projeleri Çalışması) seçilmiş otuz proje değerlendirmeye alınmıştır. Projelerin değerlendirmesini 2011-2012 öğretim yılında Türkiye'deki bir A üniversitesinin A eğitim fakültesinde Proje Tabanlı Öğrenme Uygulamaları dersini alan üçüncü sınıfta okuyan otuz öğretmen adayı yapmıştır. Araştırma sonucunda, projelerin en düşük alt boyut ölçüt puan ortalaması "Kullanılan Bilimsel Yöntem" boyutu $(\bar{X}=1,35)$, en yüksek ölçek altboyut puan ortalaması ise "Kullanışl1l11k" boyutu $(\bar{X}=1,64)$ olarak belirlenmiştir. Şaşırtıcı bir şekilde toplam kalite puanını en düşük yordayıcı boyut "Kullanılan Bilimsel Yöntem" boyutudur. Proje yarışmaları ve proje tabanlı öğrenme uygulamaları öğrencilerde bilimsel araştırma becerilerini geliştirmeyi hizmet etmesi amacıyla yapılmalıdır. Öğretmen adayları ve öğretmenlerin proje yarışmalarına bu perspektiften bakmaları için gerekli önlemler alınmalıdır.
\end{abstract}

Anahtar Kelimeler: Bilim Şenliği, Jüri Değerlendirmesi, Bilimsel Araştırma Projeleri, Regresyon Analizi

DOI No: 10.12973/nefmed.2014.8.1.a2 